\title{
Erratum to: History of narcolepsy at Stanford University
}

\author{
Emmanuel J. M. Mignot ${ }^{1}$
}

Published online: 7 May 2015

(C) Springer Science+Business Media New York 2015

\section{Erratum to: Immunol Res (2014) 58:315-339 DOI 10.1007/s12026-014-8513-4}

Findings published in Sci Transl Med. 2013 Dec 18;5(216):216ra176 by De la Herrán-Arita et al. suggesting that hypocretin/orexin itself was an auto-antigen recognized by $\mathrm{CD}^{+} \mathrm{T}$ cells in narcolepsy were recently withdrawn. Similarly, findings that molecular mimicry with specific sequences of $\mathrm{pH} 1 \mathrm{~N} 1$ had occurred have not been successfully confirmed. As a result, the Sci Transl Med. paper was withdrawn. The author wishes to delete all mention of these research findings from the History of Narcolepsy at Stanford University. This includes the section of the abstract that starts "At this date..." through the end. In addition, all description and discussion of these findings, from page 327 to the end of the article on page 333, should not be considered scientifically valid and should not be taken into consideration for future studies. The author sincerely apologizes for discussing erroneous data from his laboratory and hopes to minimize any confusion to the literature.
The online version of the original article can be found under doi: 10.1007/s12026-014-8513-4.

\section{Emmanuel J. M. Mignot}

mignot@stanford.edu

1 Stanford University Center for Sleep Sciences, 3165 Porter Drive, \#2178, Palo Alto, CA 94304, USA 